\title{
Páginas Recuperadas
}

\section{The Indian in the Latino: Genealogies of ethnicity}

\author{
Silvio Torres-Saillant \\ Syracuse University, Syracuse, NY.
}

Latino Studies (2012) 10, 587-607. doi:10.1057/lst.2012.42

\section{Ancestral Erasure}

The indigenous populations of the regions comprising the colonial dominions that the Iberian conquerors called "New Spain" and the area later claimed by the Anglo settlers as the US Southwest has endured a checkered, circuitous history of external control. Scholars date the continuous presence of indigenous peoples in these regions back to 30,000 BCE. Over millennia, they built communities, cultures and societies there until 1519 AD, when Spanish conquest and colonial domination altered their world. Historian James Diego Vigil has examined the dynamics of cultural survival and adaptation among Indian societies in these regions through the centuries, noting, inter alia, the challenges they faced during the Anglo-American and Mexicanization period, roughly from the first third of the nineteenth century to the present. Among the features that stand out in their long subordination, Vigil points to the factors that undermine their integration "into Mexican society" as well as into the United States (From Indians to Chicanos, Waveland Press, 2012, 294).

The geographical space of the early Latino experience in the United States is coterminous with the geography of indigenous lives. Latinos, as people of Hispanic descent, trace their North American roots to the Spanish settlers who spearheaded the colonial process starting with Juan Ponce de León in 1513. We look for antecedents to the Latino experience anywhere in the 
United States where Spain or subsequently the Republic of Mexico held sway politically, dictating governance structures, economic options, social relations, and cultural practices. In tracing their genealogies in North America, Latinos seldom follow the logic operative in Latin America, where a person is Latin American by ancestral connection to a place conquered and colonized by Iberia, where subsequently independent republics emerged. The same gentilitial designation applies to the groups inhabiting the region irrespective of status: descendants of Indian captives, Spanish captors, forcibly imported Africans and immigrants alike. Structures and patterns of inequality notwithstanding, conceptually the indigenous populations share the mantle of Latin-Americanness with the descendants of those who invaded them over five centuries ago.

However, in the US mainland, Latinos do not automatically see themselves sharing the same pan-ethnicity with the native inhabitants of the North American regions conquered and colonized by Spain from the sixteenth century onward. Not until the Chicano Movement's adoption of the legendary land of Aztlán did Latino discourse begin to articulate the desire to connect with pre-Hispanic ethnicity, systems of knowledge, heritage, solidarity and identity. The early Hispanic intelligentsias represented the longevity of their presence in North America by recalling their ancestors as pacifiers of barbarous Indians. Set in California after the Guadalupe-Hidalgo Treaty, The Squatter and the Don, the 1885 novel by María Amparo Ruiz de Burton puts in the mouth of Don Mariano, the patriarch of the land-owning Alamar family, a long utterance intended to explain how his class had inherited its vast holdings. It all began with "the large tracts of land" that the Spanish and the Mexican governments had given to those citizens who "would utilize the wilderness" to build villages and develop the regions involved. The Don stresses the service rendered by his ancestors in either civilizing or fighting the natives: "They also employed Indians, who thus began to be less wild. Then, in times of Indian outbreaks, the landowners with their servants would turn out, as in feudal times in Europe, to assist in the defense of the missions and the openly settled country threatened by the savages" (Ruiz de Burton, 1990, 176). Don Mariano thereby outlines the source of his economic and social privilege as the heir of ancestors who played an active role in the colonial policy of removing the natives or reducing them to servitude. Ruiz de Burton designed the characters and situations of the novel drawing largely on her own family background (Figure 1).

A similar case of Hispanic genealogy conceived as incongruent with Indian humanity appears in the writings of Jovita González, a Mexican American from Texas who flourished a generation after Ruiz de Burton. Drawing also on her own family history for a good portion of her Dew on the Thorn (1997), González evokes Don Juan José, the "first of the Olivares, who came in 1748 as Surveyor to the Spanish Crown. At the time the Indian infested region north of Nuevo León had been created into the new province of Nuevo Santander. 


\title{
THE SQUATTER
}

\author{
AND
}

\section{THE DON}

A NOVEL DESCRIPTIVE OF COMTEMPORARY OCCURRENCES

IN CALIFORNIA

C. LOYAL

\section{SAN FRANCISCO \\ 1885}

Figure 1: Cover of the original edition of the Squatter and the Don, published pseudonymously under "C. Loyal." Scholars have interpreted the "C" to stand for "Citizen."

Later, a military expedition led by Don José Escandón was sent by the Viceroy with a two-fold purpose, namely to subdue the warlike Indian tribes and to look for suitable locations for settlements in the region between Río Grande and the Nueces River" (González 3). The inherent opposition of her ancestors to the native inhabitants of the land they had invaded emerges even in descriptions of everyday life: "Captain Olivares, as did most of the rancheros, made his headquarters at Mier," where the family lived, "but whenever the Indians were at peace he took his family on occasional visits to the ranches across the Río Grande," says González (1997). Noting the patriarch’s aptitude, González describes 
how on occasion, whether "alone" or "accompanied by peones and vaqueros, he traversed the wild Indian country with the same facility as though he were traversing the plains drained by the Guadalquivir of his native Sevilla" (5). This adversial interaction with their captive host continued with the generations, as we hear in the description of Don José Alejandro, the oldest son who succeeded Captain Olivares as landlord of his domains and who married during the war of Mexican independence from Spain. "Whether as subject of his Catholic Majesty or citizen of the newly created Republic," the chief interest of Don José Alejandro, González explains, "remained ever the same, to protect his family from the Indian invasions and to increase his holdings" (6).

Don Mariano in Ruiz de Burton's novel and the scholar's voice in the text by González partake of a similar amnesia. When evoking "Indian outbreaks," "defense" of the "country threatened by the savages," the "warlike Indian tribes" and "the Indian invasions," they forget who was occupying whose land. They do not acknowledge themselves as the real stressful presence around: warlike aggressors who came from Europe unprovoked to disrupt the lives of the Indians. One might expect González, who wrote in the twentieth century, to have had occasion to integrate the Indian within a complex vision of her "Hispanic ancestry." Across the generations, at least the phenotype of the peones and vaqueros should have offered a clue to some kind of cross-racial mating. José Limón's introduction to Dew on the Thorn describes the forbears evoked by González as "Spanish-mestizo ancestors who settled this area in the 1740s" (xvi). Perhaps, the entry of the Anglo into the proscenium of Texas history, a fact witnessed by Don José Alejandro's son Cesareo, who would continue "his father work," reconfigured the Indian presence in the mind of prominent Hispanics. González tells of the moment when Cesareo learns of the gringo problem: "While at Mier, Cesareo heard the most astonishing news. The country north of the Nueces was being colonized by men who were not of the Mexican race. He was told these men were Americanos, men from the north, who came seeking homes in a land that was not theirs" (6). Dismayed to hear that the Mexican government had given the "blue-eyed strangers" permission to come, that the latter had made war against the country that gave them hospitality in order to keep the land for themselves, that first Santa Anna had prevailed against them on the battlefield and that finally they had defeated the Mexican troops, causing Santa Anna to leave the country, Don Cesareo felt that "the world was gone mad." Certainly, the world of boundless privilege that he had inherited from his forebears had reached its end.

A value of Dew on the Thorn lies in the polysemy pervading its evocation of the transition of power from the Hispanic landed gentry to the Anglo adventurers in Texas, which The Squatter and the Don had done for California. In neither case does the narration of the change of guard from Hispanic to Anglo, with its corresponding tale of woe on the dispossession of the author's ancestors, prompt an inkling of identification with the land's original 
inhabitants. Instead, their power wrenched from their hands and deprived of the option to "increase" their "holdings," which often involved making war on the natives to get them out of the way so as to build Hispanic settlements, they decreased their contact with the Indian. As a result, they simply ceased to see the indigenous communities whom they had successfully or unsuccessfully sought to vanquish. The Indian disappears from their historical discourse, and the only memory of dispossession that emerges is that which their ancestors suffered at the hands of the Anglos. They thus become the bona fide disinherited in the region, having "removed" the Indian from that rank and further submerged any thought of their previous violence against the natives. Don Cesareo regarded the Anglos as "heretics" invading a "Christian country": "He had read in a history his father left him that the Americans were the same as the English, and the English had always been the enemies of Spain," and he could not comprehend how "these vandals, these interlopers" could conceivably "take what had been given his ancestors by the king of Spain" (7). The Anglos then came to represent a moral and cultural antithesis to Hispanic humanity, fomenting an ethnic binary that reduced the Indian to insurmountable invisibility even in light of the carnal crossing that had produced the mestizos. That González upheld the ethnic binary may be deduced from her explaining in a 1981 interview the agreement she had made with her Anglo mentor J. Frank Dobie at the University of Texas, Austin, regarding their respective views on the AngloHispanic past of the region. She simply would "not go into any of his classes," she explained, adding: "I would be mad at many things. He would take the Anglo-Saxon side; naturally, I would take the Spanish and Mexican side" (Cited in Limón's “Introduction" xviii-xxi). Significantly, 2 years before her death, she had not yet managed to grasp the omission of another "side," that of the Indian.

\section{Precarious Return of the Native}

The Chicano Movement marshaled the effort to re-signify the cultural origins and ethnic heritage of Latinos, curtailing the near-monopoly of Spanish forbears and foregrounding the Indian ancestor until then marginal in the narrative of the US Hispanic past. Chicana feminism followed suit, identifying with "the" native woman via the multiple names ascribed to her in the texts of the writers, including Cihuacoatl, Coatlicue and Ixzataccihuatl from Gloria Anzaldúa to Ana Castillo. Chicana writers, Norma Alarcón has noted, reconstructed the multiple names of the Mestiza and the Indian, strategically invoking and re-codifying " 'the' native woman" to assert themselves culturally vis-à-vis the patriarchal memory of Spanish and Anglo heritages (Cultural Studies 4.3 (1990), 250, 251, 252). As Mestizaje: Critical Use of Race in Chicano Culture (2006) by Rafael Pérez-Torres suggests, Latino discourse today 
privileges a formulation of collective ancestry that integrates the Spanish forbears with the Indian ancestors, along with additional tributaries such as the African heritage, in an inclusive paradigm of hybridity and post-national claims to belonging. Pérez-Torres argues for a mestizaje that "suggests the volatility and the mutability of racial identity. Because it is an identity in the flesh, it is also tied in a profound way to the social structures and political systems through which the mestizo body moves" (xviii). Pérez-Torres invokes Alfred Arteaga's Chicano Poetics: Heterotexts and Hybridities (1997) in positing the language of the borderlands as "the site of confluence in the way the Chicano body is mestizo and the homeland is international. And like the body and home, the language is hybrid and thus more than merely a sum of its parts" (Arteaga, 1997, 16).

The formerly marginalized Indian ancestors figure implicitly in Chicano figurations of the mestizo body of the community. To what extend the discursive and visual deployment of the mestizo - with its inherent acknowledgement of non-European expressive forms, systems of knowledge and skin hues - has sufficed to restore the dignity of Indian ancestors remains less clear. Similarly, how the Chicano incorporation of the Indian subaltern in stances of community self-affirmation has extended to other subsections of the Latino population in the United States warrants examination. Latinos of South American, Caribbean and Central American origin inherit regional histories that, like those tracing their origins to the former territories of New Spain in North America, only precariously acknowledged indigenous ancestors. They have granted relevance to the Indian past mostly as props for disembodied symbolisms of national identity. As a cultural discourse of Latin American modernity, Indigenismo paid lip service to the original greatness of the autochthonous Indian civilizations while the region committed itself to nation-building programs that often involved subjugating, disinheriting and exterminating indigenous populations. Domingo Faustino Sarmiento, celebrated as an architect of Argentinian nationhood, had no qualms about overtly expressing his contempt for the Indians of his time, stigmatizing them as an obstacle to national development. The children of South American immigrants in the United States, as they construct their identity within the contours of Latino pan-ethnicity, are not very likely to cherish Indian heritage as key to their ancestry unless they have been politicized through contact with indigenous rights activism. Besides, South and Central American-descended Latinos had less of a chance, as compared with the Latino subgroups Suzanne Oboler's Ethnic Labels, Latino Lives (1995) has called "the historical minorities," namely, Mexican Americans and Puerto Ricans, to confront the dominant discourse of the US mainstream culture. As such, they have lacked an epoch-making stage comparable to the one Puerto Ricans and Chicanos encountered in the context of the Civil Rights Movement to re-signify their specific ethnic histories with an eye on breaking with racist paradigms and achieving democratic inclusiveness. 
Unlike Chicanos, however, Puerto Ricans do not hail originally from a land contiguous to the United States. They cannot stand anywhere in the southwestern portion of the US mainland and say, "the gringos took this land from our forebears." They cannot situate a Taino equivalent of Aztlán on the North American mainland. The Tainos lived overseas, on the island of Borikén, before the Spanish conquest. Puerto Ricans in the United States may claim Taino inheritance primarily through an invocation of the history of their Caribbean homeland. However, given the currency that the recovery of the indigenous memory has gained on the island over the last two decades, with some scholars and advocates arguing for the survival of aborigines even in the genetic makeup of the population, the concern for highlighting Taino heritage has spread to the Northeast, the Midwest and other parts of the US mainland where Puerto Ricans live. Taino Revival: Critical Perspectives on Puerto Rican Identity and Cultural Politics (2001), edited by Gabriel Haslip-Viera, partakes of that trend. Dominicans in the United States hail originally from a country that played a lead role in the dissemination of the Indigenista dogma in the nineteenth century. At that time, Dominican novelist Manuel de Jesús Galván achieved fame with Enriquillo $(1879,1892)$, a novel that, without indicting the conquest and colonization projects, glorifies the exploits of an Indian chief who rose against the Spanish in the colony of Santo Domingo. The book quickly became a classic of Latin American letters. However, in the United States, busy as they have been fending off charges of aberrant Negrophobia by other Latino groups and by African Americans, Dominicans have not shown great interest in recovering their ancestral homeland's Taino past. The overwhelming majority of scholarly and literary works authored by US-Dominicans reveals an engagement with blackness and a critique of Negrophobia (Figure 2).

The status of the Indian among US Cubans veers closer to that of Puerto Ricans than of Dominicans. Anthropologists and archeologists in Cuba have established compelling survivals not only of Taino but also of Carib material cultures. The best known Cuban spokesperson for indigenous identity in the United States, José Barreiro, a native of Camagüey who identifies himself as a member of the Guajiro tribe, has written a novel entitled The Indian Chronicles (1993), which, with the colony of Santo Domingo as its setting, evokes the first decades of European domination in the Caribbean. The story is told by an eyewitness, Diego Colón, not the son of the Genoese mariner, but a 12-year-old Taino boy captured by Columbus "during the first landfall in Guanahani" on 12 October 1492 (Barreiro 10). Barreiro's creation of an indigenous protagonist who, with the credentials of the eyewitness, can tell us the story of the conquest in a way that circumvents the ethnocentric bias of the Spanish chroniclers, has recurred in Latino literature. Witness the character of Huitzitzilin, Father Benito's ideological antagonist in the novel Song of the Hummingbird (1996) by the Mexican American fiction writer Graciela Limón. Remarkably, the very first novel published in the United States by 


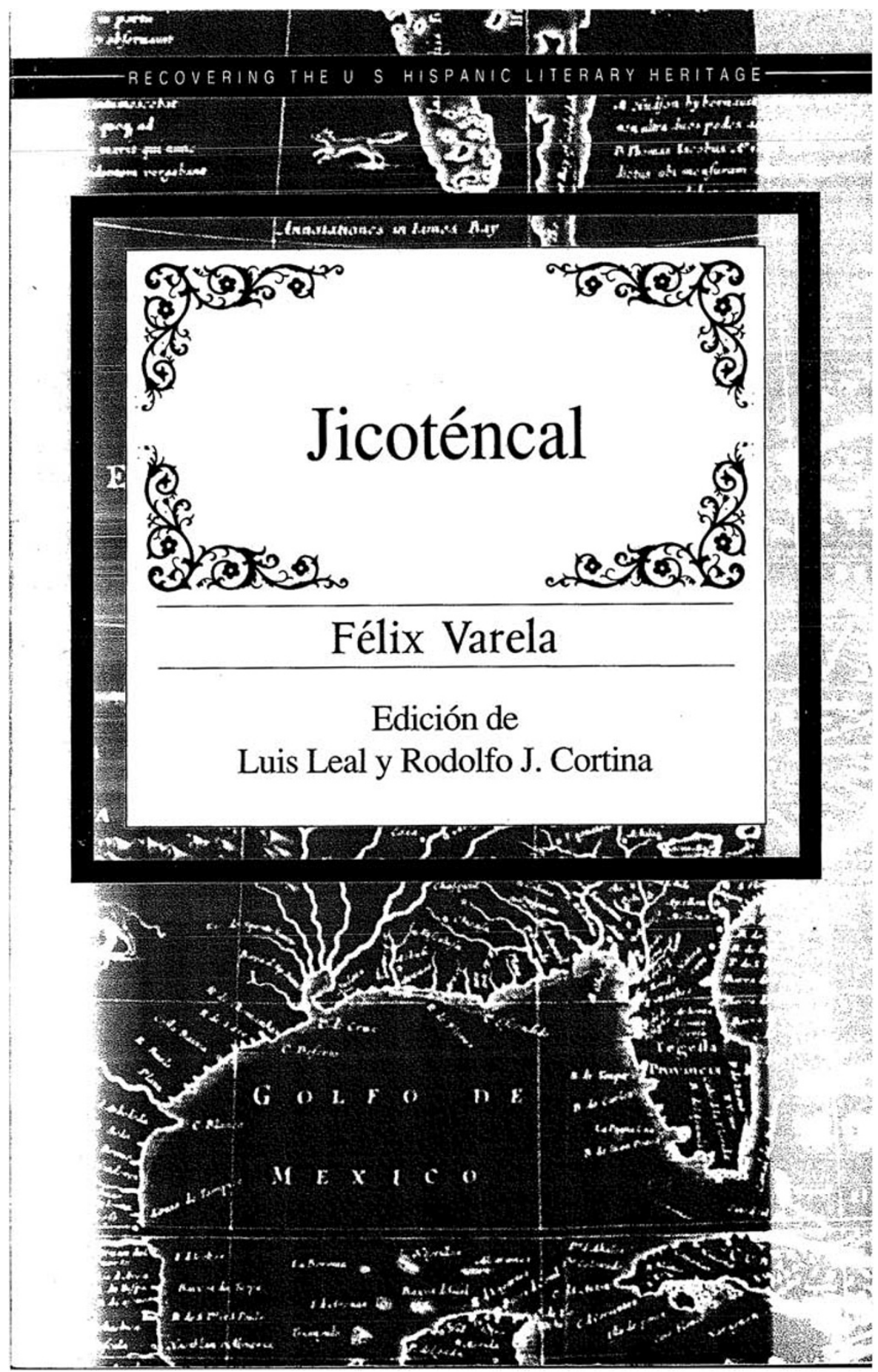

Figure 2: Cover of the 1995 recovered edition of Varela's indigenista novel. 
a Hispanic was written by a Cuban evoking indigenous society. I refer here to Félix Varela's Jicoténcal (1826), which tells the story, set in Mexico, of a Tlaxcalteca general during the period of the conquest begun by Hernán Cortés in 1519. From his base of operations in Philadelphia, Father Varela, also known as a philosopher and political ideologue, spent his long US exile promoting the cause of Cuban independence from Spanish colonial control. Luis Leal and Rodolfo Cortina, who prepared a 1995 scholarly edition of Jicoténcal for the University of Houston's Recovering the US Hispanic Literary Heritage Project, reason in their introduction that Varela used the story of Indian resistance against Cortés as a way of emboldening his compatriots to fight the colonial regime in Cuba. If so, perhaps Varela's generation did not have sufficient access to the story of Taino resistance in Cuba to enable him to set the plot of his novel locally, or perhaps he simply relied on the greater familiarity that his potential readers would have with the ancient Aztec empire than with the militarily and architecturally humbler Taino society.

The prominence of Guatemala's Rigoberta Menchu Tum, the Nobel Peace Prize-winning member of the K'iche' ethnic group, illustrates the greater visibility of indigenous peoples in Central America than in the Hispanic Caribbean. The Mesoamerican link to Mexico via Mayan Yucatan allows for a measure of contiguity to the US mainland. This link brings Central American Indians to a second order of proximity to the Aztlan territories in the Southwest, perhaps enabling them, more than Latinos of other origins, to identify with the indigeneity invoked by the Chicano Movement. Still, as I have conjectured elsewhere, if Menchù Tum settled in the United States and had US-born children, her offspring would very likely fall under the panethnic rubric of Latino rather than Native American, with uncertainty as to what would become of their pronounced indigeneity.

Given the clearer relevance that the question of indigenous ancestry has for Hispanics of the Southwest, the emphasis of the Chicano Movement in upholding the indigenous past seems unsurprising. Indeed, even before the advent of the movement, a critique of the monopoly of Spanish heritage in formulations of Southwestern cultural identity had already made its mark. Progressive California writers such as Carey McWilliams, Louis Adamic and Ruth Tuck had begun in the 1940s to lay the conceptual foundation for reducing the power of what they derisively called the "Spanish Fantasy Heritage," to which historical memory in the region had subscribed. As F. Arturo Rosales has indicated in "The Spanish Fantasy Heritage Revisited ..." (1993), Mexican American intellectuals came to challenge the memorializing that represented the better-off Hispanic families of California, New Mexico, and other Southwestern parts as direct descendants of the Spanish settlers who spearheaded the colonial transaction in North America. The discredit endured by the traditional way of remembering ancestry in the region enabled the Chicano Movement easily to toss it aside, replacing it with its own form of 
Indigenismo (Rosales 100). Rosales has argued convincingly, though, that the old Hispanic oligarchies in the Southwest were more aware of their own mestizo roots than they have gotten credit for (81).

\section{Indo-Latino Links}

In When Nickels Were Indians (1995), an autobiographical account that evokes analytically the journey of her dual Anglo and Nez Perce identity, Patricia Penn Hilden offers a few cross-ethnic snapshots that provoke reflection about the intersection of Latinos and Natives in the Los Angeles of her childhood. Remembering the overall changes that accompanied her passage to high school, she notes that: "In place of rock and roll (essential to our childhood where Ritchie Valens was the first to escape our ghetto, where pachuco dancing meant Friday nights, where Ritchie Valens's death marked our final moments in the north valley) we had an emerging world of folk music. We all took up the guitar and memorized the words to countless Joan Báez and Pete Seeger songs" (96). For the "re-memory of these events and those days," Hilden credits the poet and scholar Alfred Arteaga, whom she identifies as "a fellow native of Los Angeles who later participated in the Chicano politics that overwhelmed East Los Angeles long after we had moved north. What I remember that he doesn't, however, is how to dance the pachuco" (234). Hilden shares also the story of memorable experiences when she, while pursuing her graduate studies in history, began teaching in the Upward Bound program at the University of California, Davis. She remembers the dilemma of a 17-year-old student, "born a Navajo but raised almost entirely in San José, California, by a Chicano foster family. She had a Latina name and spoke fluent Mexican Spanish as her first language. She knew-or remembered-not a single word of Navajo" (138). The young woman, named Maria, found her way to the Tecumseh Center, where she befriended some older militant students who introduced her to Navajo ceremonies and conveyed to her their sense of her duties to the Navajo nation, resulting in a "mental fragmentation" that caused an emotional crisis, which ended up interrupting her studies (141).

One more moment in Hilden's journey into the experiential roots of her identity may invite reflection about the ties that bind Latinos and Natives. A fellow she meets at the university gives her reason to consider how they carry ubiquitously in their bodies the mark of colliding histories: "It is a peculiar tie, the mixed blood tie, artifact of racism, of an identity shattering American history. It has happened most recently in Davis with a Chicano, friend of a friend. Introduced as having two things in common - Indian blood and Los Angeles - we looked each other over: light skins, blue eyes ... you, too?" (213). What is one to make of the important place Hilden assigns in her childhood, her ghetto, to the Pachuco dance, her enthusiasm for Mexican 
American singer Ritchie Valens (formerly known as Richard Steven Valenzuela), her concern over the young woman who finds herself despairing at the intersection of Chicano and Navajo identities, her native fellowship with Arteaga and her connecting with a Chicano at the level of shared Indian ancestry, shared place and shared blue eyes? On the Nez Perce side of her ancestry, Hilden can trace her roots to the memorable Chief Joseph, and the evocation of her growing up as an "urban mixed blood" suggests a measure of comfort inhabiting a world shared by neighbors of Mexican origin. Perhaps, Hilden's recognition of Native fellowship in individuals whom our current ethnological language terms "Latinos" has something to do with what she calls the "mixed blood tie" (Figure 3).

Richard Rodríguez opens his famous autobiography Hunger of Memory (1983) with a discussion of his phenotype: "My face is drawn to severe Indian features which would pass notice on the page of a National Geographic" (3). Later in the volume, in the chapter entitled "Complexion," he distinguishes himself from his siblings in terms of facial features thus: "I am the only one in the family whose face is severely cut to the line of ancient Indian ancestors" (115). Among US writers of Hispanic descent, Rodriguez has most overtly discussed his indigenous ancestry, noting with mordant irony, as he does in a 2004 interview in the program Now: With Bill Moyers, that, on account of his Indian looks, mainstream Mexican or US Hispanic television would probably not have hired him to do the news commentaries that PBS had hired him to do. Yet, who would think of Rodríguez as a mixed-blood writer? One would think of him as a Mexican American author or, should he ever allow it, a Chicano one. Observers looking at Rodriguez, a person descended from the Republic of Mexico, which embraced mestizaje as its paradigm of national identity, would have no access to the notion of mixed-blood (Rodriguez, 1983).

The mixed-blood metaphor points to the suture that evinces the stitching together of the ancestries involved. The idea of mestizaje, on the other hand, presumes a seamless fusion of the disparate origins, conceptually erasing the memory of the coming together of differing parts, discouraging any thought of the violence behind that union. Just as Latin American intelligentsias conceived it in the nineteenth century and José Vasconcelos most succinctly articulated it in his white supremacist manifesto La raza cósmica (1925), mestizaje permits the unequal racial relations created by the colonial transaction in the Americas to remain undisturbed. By pointing to the suture, the junction made somewhat discernible by the slight roughness of the edges therein uniting, the mixed-blood metaphor provokes remembrance of the history of conflict contained in the seam. The conceptual legacy of mestizaje may in fact interfere with our remembering the native whose body and history lie dormant in the discourse of Latino identity.

As presently constituted, formulations of Latino pan-ethnicity do not make it easy for us to see, for instance, the undeniable place that the Tohono O'odham 


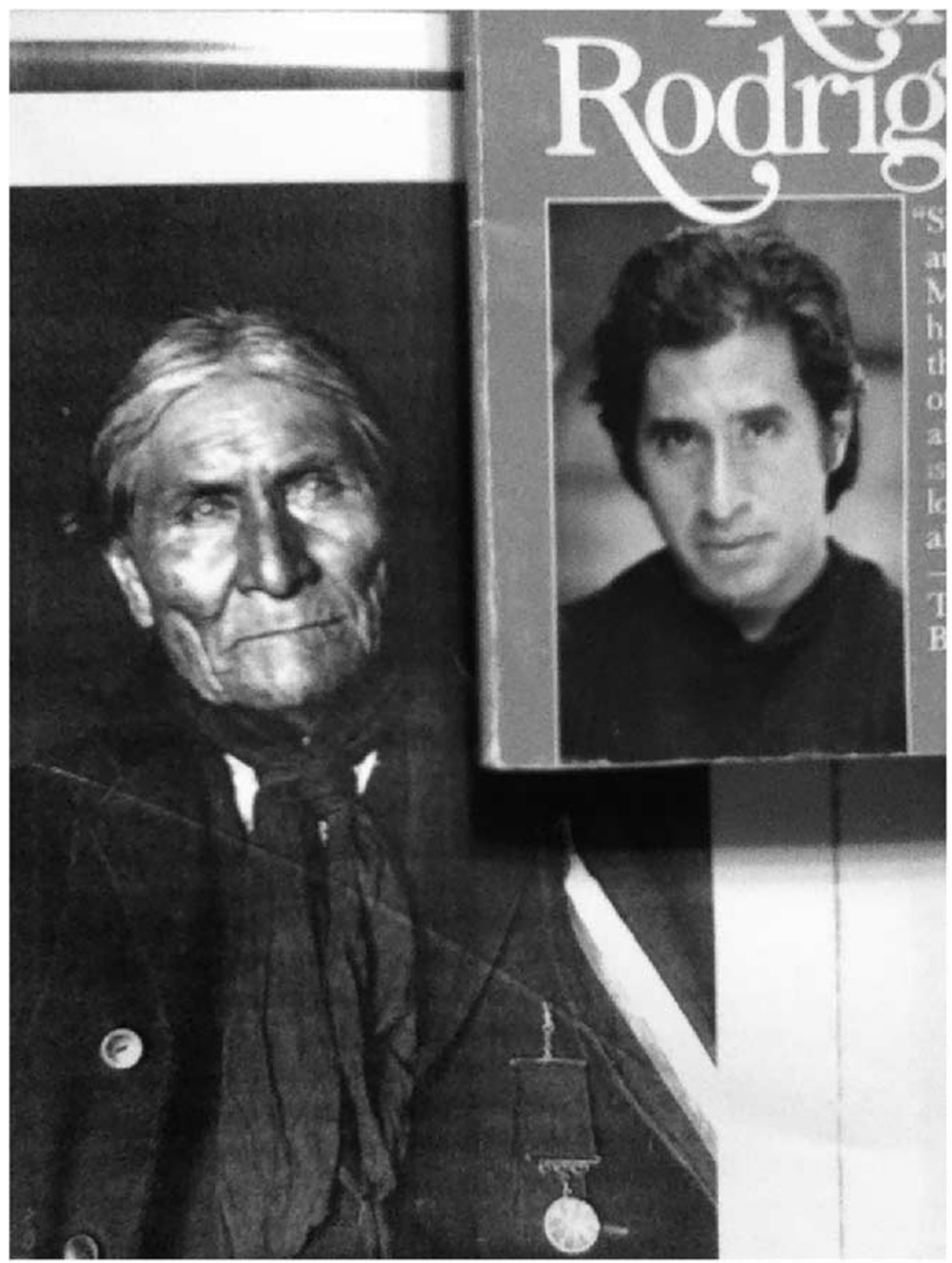

Figure 3: Composite photograph juxtaposing the "Indian face" of Richard Rodriguez from the cover of his first book and an archival picture of the Apache warrior Geronimo taken while in prison at Fort Sill (Photo credit: Nancy Kang).

should have culturally and experientially within the overall heritage of US Hispanic communities. A tribe formerly known as Papago, the O'odham come from southern Arizona, but their traditional territory continues beyond the international boundary separating the United States from Mexico. They figure among those Indian nations whose territory had the borderline drawn through their midst. As a result, among them, a family can have branches on both 
sides of the border, one living under Mexican and the other under US law. The O'odham linguist and writer Ofelia Zepeda, a native of Arizona, came from such a family. Her relatives worked harvesting cotton when she was a child, and she remembers that even in the harshness of the cotton farms they held on to traditional beliefs and observed ritual and ceremony. Zepeda's “Autobiography,” a 15-page narrative included in Here First (2000), a collection of autobiographical essays by Native American writers edited by Arnold Krupat and Brian Swann, offers the following picture of the international space in which the family's observances took place: "Many traditional practices were carried out in these communities, many of them small, private rituals involving only immediate family. For larger, important ones, ones carried out during special seasons, the families packed and went home to Sonora, Mexico, back to the traditional villages, where the ceremonies were carried out uninterrupted by the demands of the manual labor of the farms and ranches. These trips to my maternal grandmother's village in Mexico are all part of my childhood memory" (Zepeda, 2000, 409).

The practice of going back to Latin America to reconnect with relatives and tradition corresponds to a rather common feature of Latino lives in the United States. One could ask, why are the Tohono O'odham, that hail from Arizona and Mexico, territories within the domain of New Spain during the period of Spanish domination, not part of the overall Hispanic population? Is not a shared colonial control by Iberian people what links Hispanic communities to a common ancestral root? The legacy of contact with Spanish colonial overseers, who originally named them Papago, survives quite evidently in the Spanish name of Ofelia Zepeda or in that of Carlos Rios, a Tohono O'odham headman photographed by Edward Curtis before 1907. One could argue that Spanish domination exerted enough cultural influence over the best-known Pueblo nations - Tao, Acoma, Zuni, and Hopi - as to qualify them also for inclusion within the pan-ethnic sphere of Hispanics or Latinos.

The House Made of Dawn (1968), the influential Pulitzer Prize-winning novel by Native American writer N. Scott Momaday that largely led the boom of Indian literature in the United States in the latter half of the twentieth century, reflects much of the Spanish cultural influence of the Jemez Pueblo, the community that provided the author with the necessary models for designing his characters. Suffice it to mention the name of the protagonist Abel, at times given in its Spanish diminutive form as "Abelito," and some of the other characters. His grandfather Francisco raised Abel and his older brother Vidal when their mother died. The religious figures, Father Olguín and Fray Nicolas, stand out as positive forces in contrast to an Albino Indian named Juan Reyes who beat Abel or to a policeman named Martínez who handles him no less roughly. "El diablo" figures among the dark forces that haunt the imagination of the troubled Abel. The novel's references to Spanish names and beliefs may strike an uninformed reader as a borrowing from some external Hispanic culture, but for 
Momaday, whose Hispanic first name is Navarro, they represented internal cultural stimuli, a reflection of the everyday life of the Jemez Pueblo among whom he had lived. One could then reiterate the question differently, asking whether the superficial mantle of Hispanic cannot be extended to the Native peoples who lived in Arizona, Colorado, New Mexico and Texas during the long period of Spanish control of these parts. One might question the logic that traces the beginnings of the Latino population in what is now the United States only to the Spanish settlers and the mestizos they produced. Such a logic would seem to acknowledge as ancestors only those indigenous populations whom the Spanish and subsequently the Mexican landowners had defeated and successfully integrated, incorporating them as a docile workforce and carnally dominating them to produce mestizo cohorts.

In his paper for the 2006 annual conference of the Recovering the US Hispanic Literary Heritage Project, held in St Louis, Missouri, in collaboration with the Western Historical Association, the literary scholar José F. Aranda, Jr. made comments about the Chiricahua warrior Geronimo that stayed with me. I recall something to the effect that given the intensity of Geronimo's hostile engagement with the Mexican army for decades in New Mexico and Arizona, extending sometimes across the border, his story had to become part of Mexican American cultural memory. The intensity of this engagement shines forth in a passage of Geronimo's memoirs where he summarizes his long conflict with Mexicans, thus: "I have killed many Mexicans; I do not know how many, for frequently I did not count them. Some of them were not worth counting. It has been long since then, but still I have no love for the Mexicans. With me they were always treacherous and malicious. I am old now and shall never go on to the warpath again, but if I were young, and followed the warpath, it would lead into Old Mexico" (110) (Figure 4).

Geronimo, His Own Story: The Autobiography of a Great Patriot Warrior, As told to S.M. Barrett, with a dedication "to Theodore Roosevelt, President of the United States," was published in 1906, after Barrett complied with President Roosevelt's advice to "disclaim responsibility in all cases where the reputation of an individual is assailed" (44). It need not surprise us that Geronimo's autobiography, told to the recorder and editor while the Apache warrior resided in Fort Sill as a prisoner of war, contains harsher indictments of the Mexicans than of the Anglos. As Aranda sustained during his talk in St Louis, Geronimo's antipathy against Mexicans suggests the extent to which he saw his life traversed by the pervasive effect of Mexican rule on Apache territory, the area that the Spanish came to break up cartographically into such sites as Arizona and New Mexico. In that respect, the autobiography of the Apache chief could qualify as a document of Mexican American culture in the Southwest. Because it is so obvious, scholars would not generally bother to note that Geronimo answered to a Spanish name, but less obvious is the warrior's knowledge of the Spanish language, as Barrett informs us (109). Indeed, Barrett 


\section{Dedicatory}

Because he has given me permission to tell my story; because he has read that story and knows I try to speak the truth; because I believe that he is fair-minded and will cause my people to receive justice in the future; and because he is chief of a great people, I dedicate this story of my life to Theodore Roosevelt, President of the United States.

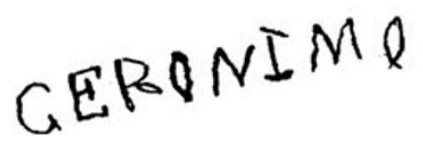

Figure 4: Dedication page of the Apache warrior's mediated autobiography with a signature showing precarious calligraphy, perhaps as a result of his old age and limited written skills. Geronimo died in 1909 , still a prisoner of war, 3 years after the book came out.

used Spanish in interviewing Geronimo for the memoir, Spanish also being the vehicle whereby he met the chief in 1904, when he interpreted for him while the latter sold a "war bonnet" to an English-speaking buyer (39).

\section{On Mestizos and Mixed-Bloods}

The Chicano enthronement of mestizo ancestry, enabled by the recognition of the Indian ancestor, coalesces with mixed-blood paradigms in compelling ways through the figure of Joaquín Murieta, which the memorable poem by Rodolfo "Corky" Gonzáles elevated as a symbol of rebellion that encapsulated the political aspirations of the Movement. The symbol comes to the Chicano space as an inheritance from the half-Anglo, half-Cherokee writer John Rollin Ridge (1955), who published under the pen name of Yellow Bird. Apart from producing the original Murieta story, a subject subsequently covered by numerous books, plays and films as imitations, adaptations and straightforward copies of the original, Ridge's version constitutes a politically radical and socially daring critique of the California establishment unparalleled by any that came after his. Luis Leal (2001) conducted copious research on the history of the Murieta story as part of an erudite introduction to the rendition by Ireneo Paz, Octavio's grandfather, published in Mexico in 1904. Leal focused, among other things, on establishing the Mexican nationality of the famous bandit in light of the tradition that locates Joaquín's birth in Chile. Nobel Prize-winning poet Pablo Neruda's play Fulgor y muerte de Joaquin Murrieta and more recently 
Isabel Allende's best-selling novel Daughter of Fortune rely on that tradition. A brief passage of Leal's introduction addresses the ethnicity of Ridge, characterizing the author's interest in a little known Mexican outlaw operating in California as a likely case of interethnic identification. "Ridge had undoubtedly suffered discrimination," says Leal, and he quotes Ridge's editor describing "the tragical event that occurred" among the Cherokee Nation following their removal from Georgia under the Andrew Jackson administration, "the stormy controversies with the whites," and the internecine conflicts that ensued, all of which Ridge as a youngster had occasion to witness first hand (Leal, 1999, xxviii).

Ridge came to the California mining country in 1850 , precisely the year when the "Foreign Miners Tax" came into effect. As Joseph Henry Jackson notes in the introduction to the 1955 edition of John Rollin Ridge's The Life and Adventures of Joaquin Murieta, the Celebrated California Bandit, the law targeted Mexicans, Chileans and Peruvians who until then had outnumbered Anglos in the gold mines (xv). The law stipulated that "foreigners" wishing to dig for gold had to buy a license that expired at the end of a 30-day cycle, when the miner would buy another, and repeat the payment with every new cycle. Failure to pay would result in the miner's expulsion by a "posse of American citizens" summoned by the sheriff. Any mining after such a violation would cost the culprit "a heavy fine and imprisonment." To ensure the collection of the fines, the governor would appoint a team of "tax collectors" whose wages consisted of a portion of the "taxes they collected" from the "foreign miners" (xvi). The Hispanics were "foreigners" almost by definition, including the Mexican natives of California who until 1848, the year of the gringo takeover of the Southwest and of the discovery of gold in California, had called the region home. Conversely, the "Germans, French, even men from Australia's convict settlements" who flooded the mines as fast as overland caravans could get them there, counted as "American" defined by consent (xvi). The year when Ridge arrives in California ushers in an era of multi-pronged abuses against Hispanics that would involve physical violence, the legislative violence represented by the Land Grant Act of 1851 and the discursive violence that ignited Hispanophobic sentiments.

As someone who had himself endured ethnic antipathy and its attending aggression, Ridge identified with the plight of Mexicans. Published in San Francisco in 1854, the year after Captain Harry Love and 20 rangers under his command collected 90 days' wages and additional rewards for presenting the head of "Joaquín" and the mutilated hand of his presumed lieutenant in a transparent glass jar, Ridge's Life of Murieta defied California's ethnic climate and political moment. He depicted a Mexican "bandit" who could kill Anglos, matching their violence in doling out revenge for the indignities he had suffered at their hands. Ridge described the Anglos as "lawless and desperate men" filled with "contempt for any and all Mexicans, whom they looked upon 
as no better than conquered subjects of the United States, having no rights which could stand before a haughtier and superior race" (9). The Anglos appear consumed by the force of their racism: "The prejudice of color, the antipathy of races, which are always stronger and bitterer with the ignorant and unlettered, they could not overcome" (10). Joaquín, by contrast, stands out for "his proud nobility of soul," apart from his "superior intelligence and education" (14-15). The narrative mourns nothing more gravely than the oppressive conditions created by the Anglos that caused Murieta to become an outlaw. The gallant Mexican hero "died in his twenty-second year," but in his short life "he displayed qualities of mind and heart which marked him as an extraordinary man," and, Ridge adds, he left "behind him the important lesson that there is nothing so dangerous as injustice to individuals - whether it arise from prejudice of color or from any other source; that a wrong done to one man is a wrong to society and to the world" (158) (Figure 5).

A mixed-blood who identified with the less empowered side of his ancestry, his Cherokee side, Ridge produced the first compelling denunciation of the prejudice, marginalization and overall oppression that Mexicans suffered as a racialized ethnic minority in the United States. Published some three decades before Ruiz de Burton's The Squatter and the Don (1885), Ridge's Life could easily qualify as the ür-text of Mexican American and Chicano counterdiscourse. Ridge's rendition of the exploits of Joaquín Murieta, the legendary hero who would go on to become "California's most enduring myth," provided the Chicano Movement, over a century later, with its most important personification of resistance. Curiously, Ridge also provided Rodolfo "Corky" Gonzáles with the title of his epic poem, the literary text best known as a cultural anthem of the Movement. The noble bandit in Ridge's Life asserts his identity when he is within shooting distance of his antagonists: "I am Joaquín! If there is any shooting to do, I am in" (31); when he is about to kill Captain Wilson, deputy sheriff of Santa Barbara County, who is after his head: "I am Joaquín" (46); and when confronting rangers who discharge their guns at him in vain: "I am Joaquin! Kill me if you can!" (87).

It may perhaps not seem too sacrilegious to propose that Ridge's Life ought to have a place among the foundational documents of Chicano or Mexican American and by extension Latino discourse. One could argue likewise for the Autobiography of Geronimo. The construction of US Hispanic identity has tended to limit the incorporation of indigenous communities to those groups that fell under Iberian colonial control from the sixteenth century onward only when the invading Spanish hordes vanquished and sufficiently domesticated them. If certain of the Indian nations who inhabited the lands of the Southwest or Texas did not suffer defeat until the arrival of the Anglo encroachers who subsequently unseated Hispanic rule in those regions, they have a harder time appearing in the genealogical tree of US Hispanic peoples. The paradigm of inclusion or exclusion seems a bit skewed to put it mildly. For all our emphasis 

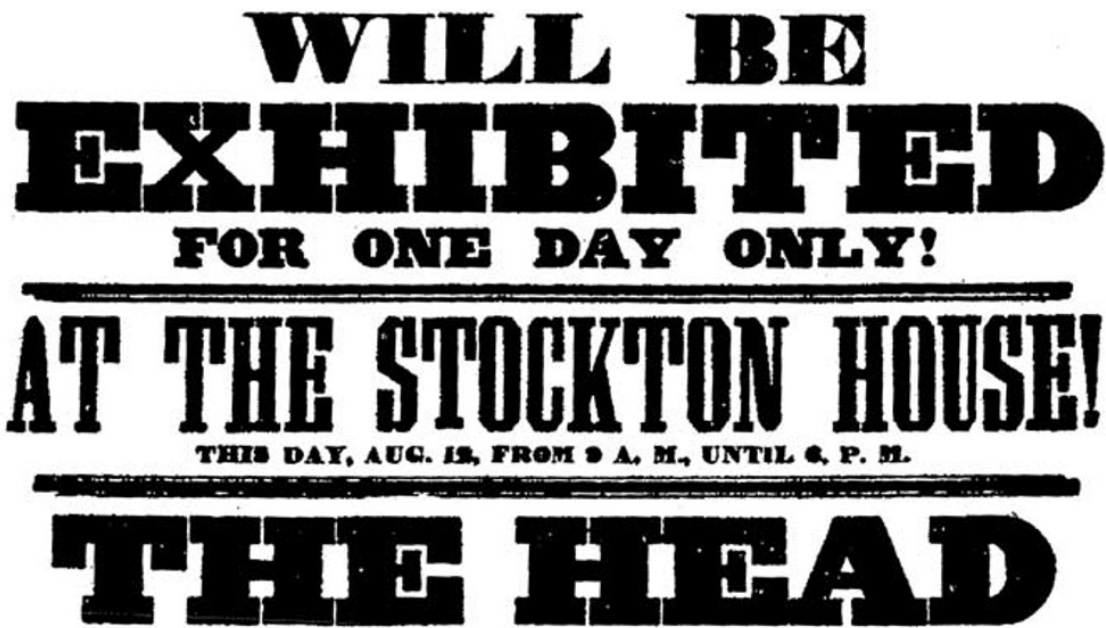

Of the renowned Bandit I
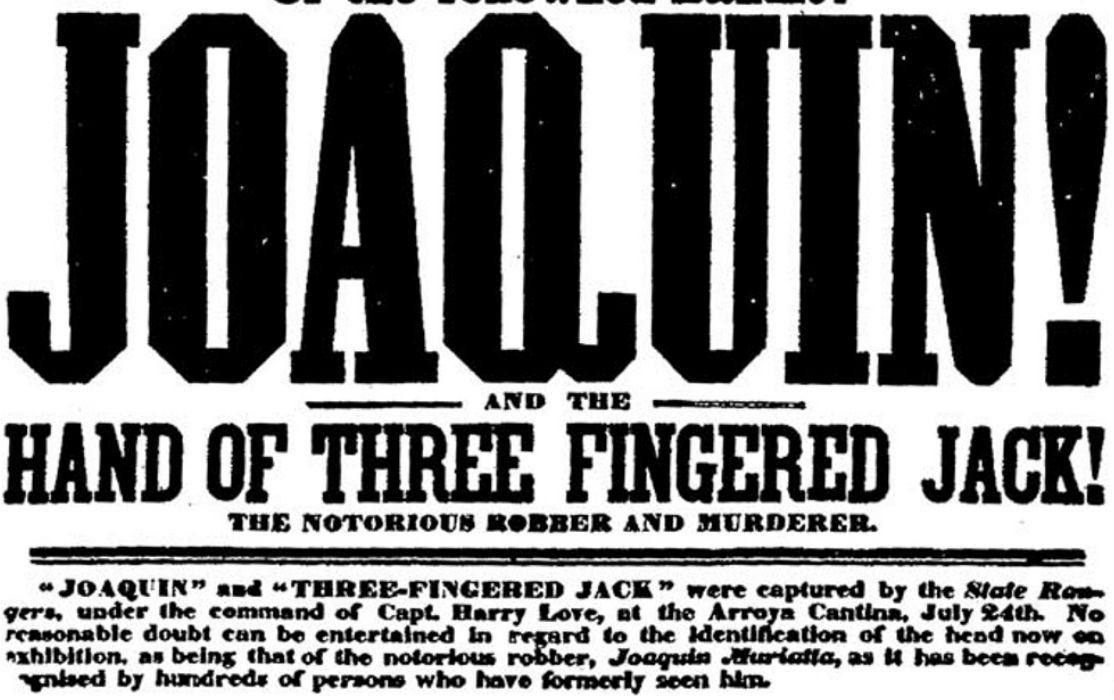

Figure 5: Poster, circulated on 12 August 1853, announcing the exhibition in Stockton, California, of the head of Murieta and the hand of his lieutenant three-fingered Jack. Captain Love and his posse had killed them on 24 July.

on traditions of resistance in our communities, we require Indians to have succumbed to Spanish or Mexican power for them to enter the contours of our pan-ethnicity. Our Spanish forbears, ironically, need to pass no such test. We acknowledge Juan de Oñate and his memorable scribe Gaspar Pérez de Villagrá as undeniable forbears even if we wish to distance ourselves from the violence they perpetrated against the Acoma in New Mexico. However, as the Apaches, also inhabitants of Spanish New Mexico, did not submit to Spanish nor Mexican power, they do not figure among the tributaries to our ancestral past. 
A deeper meditation about the logic that determined inclusion and exclusion of indigenous ancestors within the contours of US Hispanic heritage may hopefully lead to an alteration of the logic herein critiqued. I would suggest that we might look around intensely with our eyes trained on any possible traces of overlooked indigenous relatives in the Latino population's picture of its ethnic formation. The experiential identification of Cherokee half-breed John Rollin Ridge with the Mexicans of California in the early 1850s, the harsh rapport of Spanish-speaking Apache chief Geronimo with Mexican soldiers in the nineteenth century before his capture by US forces, the Hispanic background of the world evoked by Momaday's fiction (Momaday, 1968), the Chicano ambience of Nez Perce half-breed Patricia Penn Hilden in the Los Angeles of the 1950s and the Mexican family of Tohono O'odham author Ofelia Zepeda in Arizona suggest a fertile terrain for exploring ways of making the contours of Latino pan-ethnicity capacious enough to include those junctures of human experiences where Hispanic and Native American ancestries interconnect.

At the level of written cultural production, the expanded search may help us better understand the circumstances under which a "Native-Hispanic" writer would privilege one rather than the other line of ancestry in naming his or her ethnicity. One thinks of Monique Mojica, a Kuna-Rappahannock half-breed born in New York City who went over to Canada to join the Native Earth Performing Arts company in Toronto. She has written on Pocahontas and on Sacajawea. Mojica collaborates closely with the sisters Muriel Miguel, Gloria Miguel and Lisa Mayo - also Kuna-Rappahannock and Brooklyn-born - who in 1975 co-founded the Spiderwoman Theater Group. Born to Natives of the Rio Grande Valley of South Texas, the half-breed Cherokee poet Miriam Herrera often explores the Chicano and Crypto-Jewish elements of her ancestry in her work. Durango Mendoza and Vincent Mendoza, both born in Oklahoma to Creek and Mexican parents, are fine writers and activists concerned with Native American community affairs. The former serves in the American Indian Council of Illinois and the latter won the 1994 North American Indian Prose Award with his autobiography Son of Two Bloods. A Web site for "Native-Hispanic Writers" lists these authors with brief biographical details as well as others with Guajiro, Diegueño, Otomi, Apache, Yaqui, Wasco, Pueblo and Sioux ancestry on the Indian side of their mixed-blood identity.

The mixed-blood metaphor allows for the constituent parts of a person's ancestry to continue to be named as distinct ingredients, whereas in the mestizo paradigm the less empowered part of a person's parentage tends to disappear from historical memory. Perhaps, a strategic adoption of the notion of mixedblood to name the historical complexity that produced Latino populations can enable us to recognize ties to indigenous groups that we have not embraced because of a want of names to name the links between us. To some extent, our self-recognition as mixed-bloods has already started with salutary results. For some years now, we have dared to see the Black, the African-descended 
component as a distinct element in the collective ancestry of the demographic mass referred to as Latinos or Hispanics, giving rise to various Afro-Latino research and dissemination projects. Consequently, we now have knowledge about the needs, resources, challenges and possibilities of that segment of our population that we lacked before. If the indigenous component of Latino heritage became demographically discernible, moving beyond its habitual domicile in discursive abstraction, we might expand the work of cultural recovery in a way that further contributes to bringing into visibility the truly multiple visages of our people.

\section{About the Author}

Silvio Torres-Saillant, is Professor of English and Latino-Latin American Studies at Syracuse University, where he currently chairs the Humanities Council, having formerly served as William P. Tolley Distinguished Teaching Professor in the Humanities. He is an Associate Editor of Latino Studies, he formed part of the team of Senior Editors that prepared the Oxford Encyclopedia of Latinos and Latinas in the United States. He has co-edited several volumes, including Recovering the US Hispanic Literary Heritage, Vol 4 and The Challenges of Public Higher Education in the Hispanic Caribbean. He co-authored The Dominican Americans with sociologist Ramona Hernandez and has authored several books including An Intellectual History of the Caribbean. Torres-Saillant has lectured widely in the United States, Europe, Latin America, and the Caribbean (E-mail: saillant@syr.edu).

\section{References}

Alarcon, N. 1990. Chicana Feminism: In the Tracks of 'the' Native Woman. Cultural Studies 4(3): 203-212.

Arteaga, A. 1997. Chicano Poetics: Heterotexts and Hybridities. Cambridge: Cambridge University Press.

Barreiro, J. 1993. The Indian Chronicles. Houston, TX: Arte Público Press.

Galván, M.de J. 2000. Enriquillo: Leyenda Histórica Dominicana. México, DF: Editorial Porrúa.

Geronimo. 1996. In Geronimo: His Own Story: The Autobiography of a Great Patriot Warrior, As Told to S. M. Barrett, ed. F. Turner. New York: Penguin Books.

González, J. 1997. In Dew on the Thorn, ed. J. Limón. Houston, TX: Arte Público Press.

Haslip-Viera, G, ed. 2001. Taino Revival: Critical Perspectives on Puerto Rican Identity and Cultural Politics. Princeton, NJ: Markus Wiener.

Hilden, P.P. 1995. When Nickels Were Indians: An Urban, Mixed-Blood Story. Washington DC: Smithsonian Institution Press. 
Leal, L. 2001. Introduction. In Life and Adventures of the Celebrated Bandit Joaquin Murrieta: His Exploits in the State of California, ed. Ireneo Paz, trans. F.P. Belle, ix-cxi. Houston, TX: Arte Público Press.

Limón, G. 1996. Song of the Hummingbird. Houston, TX: Arte Público Press.

Momaday, N.S. 1968. The House Made of Dawn. New York: Harper \& Row.

Pérez-Torres, R. 2006. Mestizaje: Critical Use of Race in Chicano Culture. Minneapolis, $\mathrm{MN}$ : University of Minneapolis Press.

Oboler, S. 1995. Ethnic Labels, Latino Lives: Identity and Politics of (Re)Presentation in the United States. Minneapolis, MN: University of Minneapolis Press.

Ridge, J.R. 1955. In The Life and Adventures of Joaquin Murrieta, The Celebrated California Bandit, ed. J.H. Jackson. Norman, OK: University of Oklahoma Press.

Rodriguez, R. 1983. Hunger of Memory: The Education of Richard Rodriguez. New York: Bantam Books.

Rosales, F.A. 1996. 'Fantasy Heritage' Reexamined: Race and Class in the Writings of the Bandini Family and Other Californios, 1828-1965. In Recovering the US Hispanic Literary Heritage, eds. Erlinda Gonzales-Berry and Chuck Tatum, Vol. 2, 81-104. Houston, TX: Arte Público Press.

Ruiz de Burton, M.A. 1992. In The Squatter and the Don, eds. R. Sánchez and B. Pita. Houston, TX: Arte Público Press.

Varela, F. 1995. Jicoténcal, ed. L. Leal and R.J. Cortina. Houston, TX: Arte Público Press.

Vasconcelos, J. 1997. The Cosmic Race, trans. D. T. Jaen. Baltimore, MD: Johns Hopkins University Press.

Vigil, J.D. 2012. From Indians to Chicanos: The Dynamics of Mexican American Culture, 3rd edn. Long Grove, IL: Waveland Press.

Zepeda, O. 2000. Autobiography. In Here First: Autobiographical Essays by Native American Writers, eds. A. Krupat and B. Swann, 405-420. New York: Random House. 